\title{
Purification and Properties of Arylsulfatase of Klebsiella aerogenes Identity of the Enzymes Formed by Non-repressed and De-repressed Synthesis
}

\author{
Haruki Okamura, ${ }^{* 1}$ Takashi Yamada, Yoshikatsu MurookA \\ and Tokuya HARADA*2
}

Institute of Scientific and Industrial Research, Osaka University, Suita, Osaka 565

Received June 7, 1976

\begin{abstract}
Intracellular arylsulfatases from Klebsiella aerogenes W70 cells grown in methionine medium ( $M$ enzyme) and inorganic sulfate medium containing tyramine ( $T$ enzyme) were purified respectively by fractionation with $\left(\mathrm{NH}_{4}\right)_{2} \mathrm{SO}_{4}$, followed by successive chromatographies on DEAE cellulose, hydroxylapatite, Sephadex G-100 and DEAE Sephadex A-25. On polyacrylamide gel electrophoresis, the two enzymes gave single bands with the same mobilities. Molecular weights of both, determined by SDS gel electrophoresis and by Sephadex G-100 chromatography, were 47,000 and 45,000, respectively. Their activities were maximal at $\mathrm{pH} 7.5$. The affinities of the enzymes ( $\mathrm{M}$ and $\mathrm{T}$ enzymes) for their substrate $(\mathrm{Km})$ and the maximum velocity of hydrolysis $\left(V_{\max }\right)$ were enhanced by addition of electron withdrawing substituents. The enzymes were inhibited by inorganic phosphate, cyanide, hydroxylamine and tyramine. The inhibition by tyramine was competitive $\left(K i=1.0 \times 10^{-4} \mathrm{M}\right)$. These results show that the two enzymes were identical. This was confirmed by the fact that mutant strains, which were unable to synthesize arylsulfatase when grown with methionine, could also not synthesize the enzyme when grown with tyramine.
\end{abstract}

Arylsulfatase (EC 3.1.6.1) occurs in most animal tissues and in many microorganisms. Its widespread distribution suggests that it may have a rather fundamental function, but little is known about this.

In some strains in Enterobacteriaceae, arylsulfatase synthesis is controlled by sulfur containing compounds and some aryl compounds in the medium. Most early work on regulation of arylsulfatase synthesis was done with Aerobacter aerogenes ATCC 9621. 1 5) This organism synthesizes arylsulfatase when grown in medium containing methionine, taurine or choline sulfate as the sulfur source (non-repressed condition) and the synthesis is repressed using inorganic sulfate, or any of the sulfur compounds which are thought to be direct intermediates in the conversion of sulfate to cysteine as the sulfur source., ) Addition of tyramine to the medium reversed

\footnotetext{
*1 Present address: Institute for Microbial Diseases, Osaka University.

*2 To whom reprint requests should be sent.
}

the repression of arylsulfatase synthesis ${ }^{1,6}$ (de-repressed conditon). Strains of this species are now classified as members of the Enterobacter, Klebsiella or Erwina. A. aerogenes ATCC 9621 does not have a suitable genetic exchange system. Thus, we selected Klebsiella aerogenes W70, in which the genetic material can be transferred, for further studies on regulation of arylsulfatase synthesis. In strain W70, regulation is similar to that observed in strain ATCC 9621 and its mechanism has been studied in detail. ${ }^{7,8)}$

This paper reports the purification and properties of the enzyme from $K$. aerogenes W70 and the identity of the enzyme synthesized in methionine medium with the enzyme synthesized in sulfate medium on derepression by tyramine.

\section{MATERIALS AND METHODS}

Strains. Klebsiella aerogenes W70 was principally used. Its derivatives, K13 and K17 and other mutant 
strains derived from $\mathrm{K} 13$ or $\mathrm{K} 17$ were used in some experiments.

Culture conditions. The cultures were grown aerobically at $30^{\circ} \mathrm{C}$ in minimal medium containing

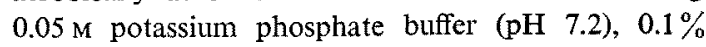
$\mathrm{NH}_{4} \mathrm{Cl}, 0.01 \% \mathrm{MgCl}_{2} \cdot 6 \mathrm{H}_{2} \mathrm{O}, 0.001 \%$ each of $\mathrm{NaCl}$, $\mathrm{MnCl}_{2} \cdot 4 \mathrm{H}_{2} \mathrm{O}$ and $\mathrm{FeCl}_{8} \cdot 6 \mathrm{H}_{2} \mathrm{O}, 0.5 \%$ xylose and $1 \mathrm{~mm}$ sulfur compound. Methionine was used as the sulfur source for non-repressed synthesis of arylsulfatase and inorganic sulfate plus tyramine $(3 \mathrm{~mm})$ were used for derepressed synthesis of the enzyme. Growth was followed in a Klett-Summerson Colorimeter (590 $660 \mathrm{~nm}$ ), calibrated by dry weight determination.

Arylsulfatase assay. Arylsulfatase activity was measured photometrically using $p$-nitrophenyl sulfate (PNPS) as substrate. When whole cells were used as enzyme preparation, they were collected by filtration on Whatman glass fiber paper $G F / B$ with aspiration and washed with $5 \mathrm{ml}$ of $0.1 \mathrm{M}$ Tris (hydroxymethyl) aminomethane, (Tris)-chloride buffer, pH 7.5. Enzyme preparation $(0.5 \mathrm{ml})$ was mixed with $2.5 \mathrm{ml}$ of the same buffer containing $7.5 \mu$ mole of PNPS, and the reaction mixture was incubated for 5 to $20 \mathrm{~min}$ at $30^{\circ} \mathrm{C}$. Reactions were terminated at appropriate times by adding $0.5 \mathrm{ml}$ of $1 \mathrm{~N} \mathrm{NaOH}$ containing $0.1 \mathrm{M} \mathrm{Na} \mathrm{NO}_{4}$. The fiber paper and cells were removed by centrifugation, and the optical density of the supernatant was measured in a Hitachi Spectrophotometer, Typer 124 at $400 \mathrm{~nm}$. One unit of activity was defined as the amount causing liberation of $1 \mu$ mole of $p$-nitrophenol per min. To study substrate specificity, the arylsulfatase activities towards various substrates were assayed by the method of Dodgson and Spencer $\left.{ }^{9}\right)$ with the modification that $0.5 \mathrm{ml}$ of the enzyme preparation in a centrifuge tube was mixed with $1 \mathrm{ml}$ of substrate solution in $0.1 \mathrm{~m}$ Tris-chloride buffer, $\mathrm{pH}$ 7.5.

Tests on inhibition by chemical compounds. The enzyme activity was assayed using $20 \mu \mathrm{g}$ of purified enzyme per ml. After neutralization of aqueous solution of the compounds by adding hydrochloric acid, they were added to the enzyme solution in Tris-chloride buffer $\mathrm{pH} 7.5$, prior to initiation of the reaction by addition of PNPS.

Protein concentrations. Protein concentrations were determined by the method of Lowry et al. ${ }^{10}$ ) with bovine serum albumin as a standard.

Electrophoretical analysis. Polyacrylamide gel electrophoresis was carried out by the method of Davis. ${ }^{11)}$ The concentration of polyacrylamide was $7.5 \%$ and each column was run at $5 \mathrm{~mA}$ in Trisglycine buffer, $\mathrm{pH}$ 8.3. Coomassie Brilliant Blue $(0.2 \%)$ in methanol-acetic acid- $\mathrm{H}_{2} \mathrm{O}(5: 1: 5, \mathrm{v} / \mathrm{v})$ was used for staining protein bands and the pigment in free form was removed by soaking the gel in 7\% acetic acid solution. For detection of the locus of the enzyme in the gel, the gel was soaked in $5 \mathrm{~mm} p$ nitrophenyl sulfate solution.

Molecular weight. Molecular weight was determined by SDS-gel electrophoresis and by Sephadex G-100 column chromatography, following the methods of Weber and Osborn, ${ }^{12)}$ and Whitaker, ${ }^{13)}$ respectively.

Chemicals. Tyrosine-o-sulfate and tyramine-osulfate were synthesized by the method of Dodgson et al. ${ }^{14)}$ We prepared phenyl sulfate, $o-, m$ - and $p$ nitrophenyl sulfate and $o$-, $m$ - and $p$-carboxyl phenyl sulfate and phenolphthalein disulfate by a modification of the method of Whitehead et al. ${ }^{15)} p$-Nitro-catechol sulfate and indoxyl sulfate were obtained from Sigma Chemicals Co. Other chemicals were of the purest grade available commercially.

\section{RESULTS}

\section{Purification of arylsulfatase}

The cells when grown on methionine medium (non-repressed condition) and on inorganic sulfate medium containing tyramine (derepressed condition) were used as the sources of arylsulfatase. All operations were performed at $5^{\circ} \mathrm{C}$. At first, cells in stationary growth phase were harvested from the cultures in 30 liters of methionine medium.

Step 1. The cells were washed with $0.1 \mathrm{M}$ Tris-chloride buffer, $\mathrm{pH} 7.5$, suspended in the same buffer and then disrupted by sonication for $5 \mathrm{~min}$ at $20 \mathrm{KC}$ in a Ultrasonic Oscillator (Kaijo-Denki, Type 4280) in ice water. The cell debris was removed by centrifugation at $50,000 \times g$ for $20 \mathrm{~min}$ and $900 \mathrm{ml}$ of supernatant, containing about 1,400 units of arylsulfatase, were obtained as crude enzyme.

Step 2. Solid ammonium sulfate was added to the crude enzyme with stirring to give a final saturation of $55 \%$. The precipitate formed was removed by centrifugation for $20 \mathrm{~min}$ at $15,000 \mathrm{~g}$ and the supernatant was brought to $80 \%$ saturation of ammonium sulfate by further addition of the salt. The resulting precipitate was collected by centrifugation and dissolved in $80 \mathrm{ml}$ of $0.02 \mathrm{M}$ 
Tris-chloride buffer, $\mathrm{pH}$ 7.4. This solution was dialyzed against the same buffer.

Step 3. The dialyzed material was applied to a column $(3.5 \times 20 \mathrm{~cm})$ of DEAE cellulose equilibrated with $0.02 \mathrm{M}$ Tris-chloride buffer containing $0.05 \mathrm{M} \mathrm{NaCl}$. The column was washed with $200 \mathrm{ml}$ of the equilibration buffer, and then elution was performed with a linear concentration gradient of $0.05 \mathrm{M} \mathrm{NaCl}$ to $0.15 \mathrm{M} \mathrm{NaCl}$ (450 ml each) in the same buffer. Arylsulfatase was eluted with about $0.1 \mathrm{M} \mathrm{NaCl}$. One peak of arylsulfatase activity appeared. The fractions $(40 \mathrm{ml})$ containing enzyme activity were combined, and the material with activity was precipitated with ammonium sulfate (90\% saturation), dissolved in $0.02 \mathrm{M}$ potassium phosphate buffer, $\mathrm{pH} 7.2$ and dialyzed against the same buffer.

Step 4. The dialyzate was charged on a column $(3.5 \times 7 \mathrm{~cm})$ of hydroxylapatite equilibrated with $0.02 \mathrm{M}$ potassium phosphate buffer, pH 7.2. The column was eluted with a linear concentration gradient of $0.02 \mathrm{M}$ to $0.15 \mathrm{M}$ potassium phosphate buffer $(200 \mathrm{ml}$ each). The fractions with activity $(40 \mathrm{ml})$ eluted from the column with about $0.08 \mathrm{M}$ buffer were combined.

Step 5. The combined solution was concentrated by filtration through collodion membrane and applied to a column $(2.5 \times 100 \mathrm{~cm})$ of Sephadex G-100 equilibrated with $0.02 \mathrm{M}$ Tris-chloride buffer, pH 7.2. Elution was carried out with the same buffer and the fractions $(20 \mathrm{ml})$ with high arylsulfatase activity were combined.
Step 6. The enzyme solution was concentrated by using collodion bag and applied to a column $(2.2 \times 21 \mathrm{~cm})$ of DEAE Sephadex A-25 equilibrated with $0.02 \mathrm{M}$ Tris-chloride buffer, containing $0.01 \mathrm{M} \mathrm{NaCl}$. Elution was performed with a linear gradient of $0.01 \mathrm{M}$ to $0.06 \mathrm{M} \mathrm{NaCl}$. Arylsulfatase activity emerged as a single symmetrical peak coinciding with that of protein, as shown in Fig. 1. Fractions Nos. 47 to 60 were combined.

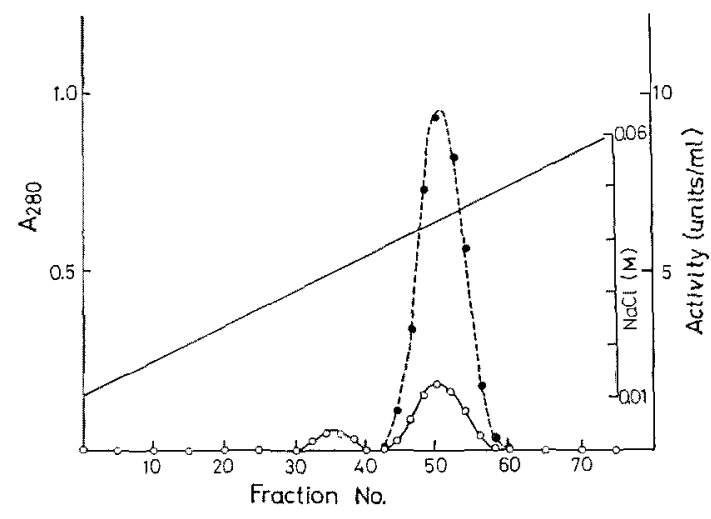

FiG. 1. Elution Pattern of Arylsulfatase (M Enzyme) from a DEAE Sephadex A-25 Column.

Symbols: $O$, absorbance at $280 \mathrm{~nm}$; , arylsulfatase activity.

The purification procedure is summarized in Table I. The arylsulfatase was purified about 1400-fold (specific activity 56 units/mg protein) with a yield of about $1.8 \mathrm{mg}$ of enzyme from 30 liters of culture. This enzyme was designated as $M$ enzyme. By a similar method, about $2.8 \mathrm{mg}$ of purified arylsulfatase, specific activity of 54 units/mg, were obtained from the cells grown in a medium containing inorganic sulfate and tyramine. This enzyme was designated as $T$ enzyme.

Table I. Enzyme Purification

\begin{tabular}{llcrrrrr}
\hline \multicolumn{1}{c}{ Step } & $\begin{array}{c}\text { Volume } \\
\mathrm{ml}\end{array}$ & $\begin{array}{c}\text { Protein } \\
\mathrm{mg}\end{array}$ & $\begin{array}{c}\text { Total } \\
\text { activity } \\
\text { (units) }\end{array}$ & $\begin{array}{c}\text { Specific } \\
\text { activity } \\
\text { (units/mg) }\end{array}$ & $\begin{array}{c}\text { Recovery } \\
\%\end{array}$ \\
\hline 1 & Crude enzyme & 900 & 35,020 & 1,401 & 0.04 & 100 \\
2 & $\left(\mathrm{NH}_{4}\right)_{2} \mathrm{SO}_{4}, 55 \sim 80 \%$ satn. & 80 & 6,840 & 1,052 & 0.15 & 75 & 54 \\
3 & DEAE cellulose & 40 & 330 & 756 & 2.3 & 7.5 & 39 \\
4 & Hydroxylapatite & 40 & 72 & 540 & 136 & 31 & 10 \\
5 & Sephadex G-100 & 20 & 4.4 & 100 & 56 & 7 \\
6 & DEAE Sephadex A-25 & 14 & 1.8 & 100 & & &
\end{tabular}


Purities of the preparations of arylsulfatase

On disc-gel electrophoresis at $\mathrm{pH} 8.3$, both purified enzyme preparations behaved as single protein with an identical mobility as shown in Fig. 2. The protein bands were completely coincided with activity bands. The molecular weights of the enzymes ( $M$ and T) were both determined to be 47,000 by SDS gel electrophoresis and 45,000 by Sephadex G-100 column chromatography. Thus the two preparations had the same molecular weights in monomeric form. Activity was maximal at $\mathrm{pH} 7.5$, and at $40^{\circ} \mathrm{C}$ in a $30-\mathrm{min}$ reaction period. Nearly half the activity was lost on incubation for $5 \mathrm{~min}$ at $60^{\circ} \mathrm{C}$.

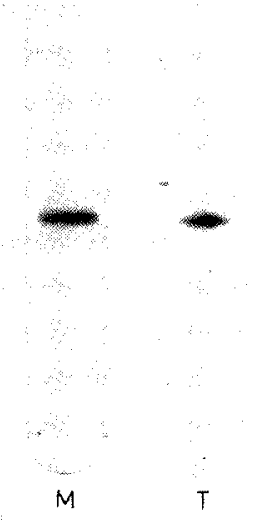

FIG. 2. Polyacrylamide Disc Electrophoresis of Purified Arylsulfatase from Cells Cultured in Methionine Medium (M) and in Inorganic Sulfate and Tyramine Medium $(T)$.

\section{Substrate specificity}

The $K m$ and $V_{\max }$ values of the $\mathrm{M}$ enzyme are shown in Table II. The enzyme showed rather high affinities and high activities towards $o-, m$ - and $p$-nitrophenyl sulfates and nitrocatechol sulfate but low affinities and low activities towards phenyl sulfate and $\mathrm{m}$ carboxyphenyl sulfate. The affinities for tyrosine- and tyramine-o-sulfates and indoxyl sulfate were high but the activities were rather low. No activities towards $o$ - and $p$-carboxyphenyl sulfates and phenolphthaleine disulfate were detected. Similar values were obtained for the two enzymes. Thus, like arylsulfatase of Alcaligenes metalcaligenes ${ }^{16)}$ the affinities of the enzyme for substrates $(K m)$ and the
Table II. Michaelis Constants AND $V_{\text {max }}$ OF Arylsulfatase (M ENZYME) OF $K$. aerogenes W70

\begin{tabular}{lcc}
\hline \multicolumn{1}{c}{ Substrate } & $\begin{array}{c}K m \\
\left(\times 10^{-4} \mathrm{M}\right)\end{array}$ & $\begin{array}{c}V_{\max } \mu \mathrm{mole} \\
\mathrm{SO}_{4}^{2-} \text { liber- } \\
\text { ated/min/mg } \\
\text { protein }\end{array}$ \\
\hline Phenyl sulfate & 50 & 5 \\
$o$-Nitrophenyl sulfate & 6 & 98 \\
$m$-Nitrophenyl sulfate & 7 & 126 \\
$p$-Nitrophenyl sulfate & 9 & 86 \\
$o$-Carboxyphenyl sulfate & - & 0 \\
$m$-Carboxyphenyl sulfate & 50 & 4 \\
$p$-Carboxyphenyl sulfate & - & 0 \\
$p$-Nitrocatechol sulfate & 9 & 95 \\
Tyrosine- 0 -sulfate & 10 & 9 \\
Tyramine- $o$-sulfate & 9 & 2 \\
lndoxyl sulfate & 11 & 4 \\
Phenolphthaleine disulfate & - & 0 \\
\hline
\end{tabular}

maximum velocities of hydrolysis $\left(V_{\max }\right)$ were enhanced by addition of electron withdrawing substituents.

\section{Inhibition of the enzyme}

The effects of various metal ions on the enzyme activity ( $M$ enzyme) were examined. $\mathrm{Na}^{+}, \mathrm{K}^{+}, \mathrm{Mn}^{2+}, \mathrm{Mg}^{2+}$ and $\mathrm{Ca}^{2+}$ had no effect, but addition of $25 \mathrm{mM}$ of $\mathrm{NH}_{4}{ }^{+}$activated the enzyme by $60 \% \mathrm{NH}_{4}{ }^{+}$and $\mathrm{Mg}^{2+}$ have been found to activate the crude enzyme from $A$. aerogenes ATCC 9621. ${ }^{8}$ Inhibitory effects of inorganic sulfate, sulfite, phosphate, fluoride, hydroxylamine and cyanide were also investigated (Table III), for comparison with their reported-effects on arylsulfatase. A concentration of $25 \mathrm{~mm}$ sodium sulfate did not inhibit the enzyme activity while similar concentrations of sodium sulfite and sodium phosphate caused about $40 \%$ and $80 \%$ inhibition, respectively. Cyanide at a concentration of $25 \mathrm{~mm}$ inhibited the enzyme activity almost completely, whereas fluoride was not inhibitory. Hydroxylamine was strongly inhibitory, causing about $90 \%$ inhibition, even at a concentration of $2.5 \mathrm{~mm}$. Furthermore, effects of several amine compounds on the enzyme action were investigated (Table IV). Tyramine, octopamine and dopamine gave significant inhibitory effect, but no effects were observed with tryptamine and 
TABLE III. INHIBITIONS BY INORGANIC COMPOUNDS

\begin{tabular}{lccc}
\hline \multirow{2}{*}{ Addition } & \multicolumn{3}{c}{ Relative activity } \\
\cline { 2 - 4 } & 0 & $2.5 \mathrm{mM}$ & $25 \mathrm{mM}$ \\
\hline None & 100 & -- & -- \\
$\mathrm{Na}_{2} \mathrm{SO}_{4}$ & & 97 & 95 \\
$\mathrm{Na}_{2} \mathrm{SO}_{3}$ & & 89 & 61 \\
$\mathrm{Na}_{8} \mathrm{PO}_{4}$ & & 61 & 21 \\
$\mathrm{NaF}$ & & 100 & 100 \\
$\mathrm{NH}_{2} \mathrm{OH}$ & & 8 & 0 \\
$\mathrm{KCN}$ & & 32 & 5 \\
\hline
\end{tabular}

Table IV. Inhrittions by Amine Compounds

\begin{tabular}{lccc}
\hline \multirow{2}{*}{ Addition } & \multicolumn{3}{c}{ Relative activity } \\
\cline { 2 - 4 } & 0 & $2.5 \mathrm{mM}$ & $25 \mathrm{mM}$ \\
\hline None & 100 & - & - \\
Tyramine & & 24 & 8 \\
Dopamine & & 21 & 5 \\
Octopamine & & 37 & 13 \\
Tryptamine & & 100 & 97 \\
Histamine & & 100 & 100 \\
\hline
\end{tabular}

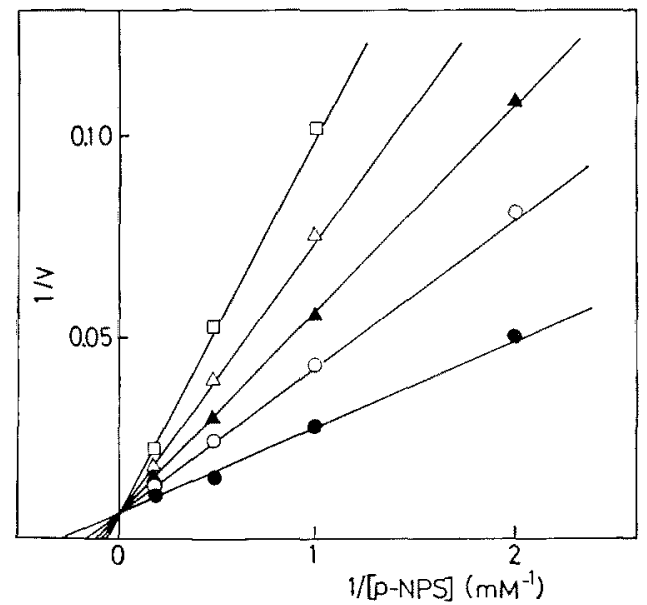

FlG. 3. Inhibition of Arylsulfatase $M$ by Tyramine. Lineweaver-Burk reciprocal plot of the effect of tyramine concentrations at various PNPS concentrations on enzyme. Symbols: $\bullet 0.1 \mathrm{~mm}$; $0,0.25 \mathrm{~mm}$; $\Delta, 0.75 \mathrm{mM}, \triangle, 1.0 \mathrm{mM} ; \square, 1.5 \mathrm{~mm}$ of tyramine.

histamine. Kinetic studies showed that inhibition by tyramine was competitive as shown in Fig. 3 and the $K i$ value was $1.0 \times$ $10^{-4}$. These results are of great importance and interest because this inhibition is highly specific and the enzyme synthesis is also induced specifically by these compounds.
Recently tyramine and a number of phenols have been shown to enhance the activity of the arylsulfatase of Aspergillus oryzae ${ }^{17}$ and their effects were found to be due to phenol sulphotransferase activity caused by the arylsulfatase itself. The enzyme of strain W70 did not exhibit phenol sulfotransferase activity, even when phenol or tyrosine was added in place of tyramine. The inhibitions of $T$ enzyme by inorganic sulfite, inorganic phosphate, hydroxyamine, cyanide and tyramine were the same as those of $M$ enzyme.

\section{DISCUSSION}

The enzyme of $K$. aerogenes W70 exhibits appreciable activity and affinity toward $p$ nitrophenyl sulfate and nitrocatechol sulfate and is inhibited by cyanide and inorganic phosphate. Thus, like the enzyme from $A$. aerogenes ATCC 9621 it cannot be classified under Type 1 or 2 of Dodgson and Spencer. ${ }^{183}$ It is characteristic that the enzyme isolated here is specifically inhibited by tyramine.

It has been reported that in some microorganisms different arylsulfatase are synthesized by a single strain. Harada ${ }^{193}$ suggested that a strain of Pseudomonas aeruginosa produces two different arylsulfatases when grown in a medium containing an arylsulfate ester as sulfur source. Furthermore, Delisle and Milazzo ${ }^{203}$ showed that a strain of this species can synthesize two forms of arylsulfatase (charge isomers) even in a medium containing methionine as sulfur source. The presence of multiple electrophoretic species of arylsulfatase in sonicated preparation of Proteus rettger $i,{ }^{21)}$ has been demonstrated by disc electrophoresis. Two distinct fractions of arylsulfatase of Aspergillus nidulans, having different $K m$ values for $p$-nitrophenyl sulfate and nitrocatechol sulfate, were separated by DEAEcellulose chromatography. ${ }^{22}$ Fowler and Rammler ${ }^{2 \hat{3}}$ purified the enzyme of $A$. aerogenes ATCC 9621 from the cells grown in a medium containing methionine as the sulfur source, and found that it was homogeneous in molecular size. 
Table V. Levels of Arylsulfatase Activity in Mutant Strains ${ }^{a}$ )

\begin{tabular}{lccc}
\hline & \multicolumn{3}{c}{$\begin{array}{c}\text { Arylsulfatase activity } \\
\text { cells grown on }\end{array}$} \\
\cline { 2 - 4 } Strain $^{-3}$ units/mg \\
\cline { 2 - 4 } & Methionine & $\mathrm{Na}_{2} \mathrm{SO}_{4}$ & $\begin{array}{c}\mathrm{Na}_{2} \mathrm{SO}_{4}+ \\
\text { Tyramine }\end{array}$ \\
\hline $\mathrm{K} 13$ & 2.32 & 0.06 & 2.42 \\
$\mathrm{~K} 601$ & 0.02 & 0.01 & 0.01 \\
$\mathrm{~K} 64$ & 0.04 & 0.03 & 0.02 \\
$\mathrm{~K} 606$ & 0.04 & 0.02 & 0.02 \\
$\mathrm{~K} 608$ & 0.04 & 0.02 & 0.03 \\
$\mathrm{~K} 174$ & 0.07 & 0.01 & 0.01 \\
$\mathrm{~K} 176$ & 0.07 & 0.07 & 0.12 \\
$\mathrm{~K} 1739$ & 0.02 & 0.02 & 0.02 \\
\hline
\end{tabular}

a) Overnight growing cells cultured in minimal medium containing $1 \mathrm{~mm}$ sulfur compound with or without $3 \mathrm{~mm}$ tyramine were used for the assay of arylsulfatase activity.

b) Mutant strains K601, K604, K606, and K608 were derived from K13 and K174, K176 and K1739 were derived from K17.2)

In our work the preparations of arylsulfatase produced by non-repressed and de-repressed synthesis in $K$. aerogenes W70 were each found to contain a single enzyme. Furthermore it was found that the same enzyme was synthesized under the two conditions. This was demonstrated by studies on the electrophoretic characteristics, molecular weights, substrate specificities and inhibition of the two preparations of arylsulfatase. To confirm that this strain produces only one arylsulfatase, experiments were made to see whether mutant strains incapable of synthesizing the enzyme when grown with methionine as the sole source of sulfur, could synthesize the enzyme when grown with tyramine and inorganic sulfate. As shown in Table V, these mutants did not synthesize the enzyme in either medium. Thus, these strains were mutants deficient in the single structural gene for arylsulfatase. This is further evidence that only one aryl- sulfatase is produced in this organism.

\section{REFERENCES}

1) T. Harada, Bull. Agr. Chem. Soc., Japan, 21, 267 (1957).

2) T. Harada, ibid., 23, 222 (1959).

3) T. Harada and K. Kono, Nippon Nógeikagaku Kaishi, 28, 608 (1954).

4) T. Harada and B. Spencer, Biochem. J., 93, 373 (1964).

5) D. H. Ranmler, C. Crado and L. R. Fowler, Biochemistry, 3, 224 (1964).

6) T. Adachi, Y. Murooka and T. Harada, J. Bacteriol., 116, 19 (1973).

7) T. Adachi, Y. Murooka and T. Harada, ibid., 121, 29 (1975).

8) T. Adachi, H. Okamura, Y. Murooka and T. Harada, ibid., 120, 880 (1974).

9) K. S. Dodgson and B. Spencer, Biochem. J., 55, 436 (1953).

10) O. H. Lowry, N. J. Rosebrough, A. L. Farr and R. J. Randall, J. Biol. Chem., 193, 265 (1951).

11) B. J. Davis, Ann. N.Y. Acad. Soc., 121, 404 (1964).

12) K. Weber and M. Osborn, J. Biol. Chem., 244, 4406 (1964).

13) J. R. Whitaker, Anal. Chem., 35, 1950 (1963).

14) K. S. Dodgson, F. A. Rose and N. Tudball, Biochem. J., 71, 10 (1959).

15) J. E. M. Whitehead, A. R. Morrison and L. Young, ibid., 51, 585 (1952).

16) K. S. Dodgson, B. Spencer and K. Williams, ibid., 64, 216 (1956).

17) G. R. Burns and C. H. Wynn, ibid., 149, 697 (1975).

18) K. S. Dodgson and B. Spencer, Methods of Biochem. Analy., 4, 212 (1957).

19) T. Harada, Biochim. Biophys. Acta, 81, 193 (1964).

20) G. J. Delisle and F. H. Milazzo, Can. J. Microbiol., 18, 561 (1972).

21) J. W. Fitzgerald and F. H. Milazzo, ibid., 16, 1109 (1970).

22) B. N. Apte and O. Siddiqi, Biochim. Biophys. Acta, 242, 129 (1971).

23) L. R. Fowler and D. H. Rammler, Biochemistry, 3, 230 (1964). 